\title{
MGMT assessment in pituitary adenomas: comparison of different immunohistochemistry fixation chemicals
}

\author{
Alexander S. G. Micko ${ }^{1,2} \cdot$ Romana Höftberger $^{2} \cdot$ Adelheid Wöhrer $^{2} \cdot$ Matthias Millesi $^{1}$ - Engelbert Knosp ${ }^{1}$. \\ Stefan Wolfsberger ${ }^{1}$
}

Published online: 17 January 2018

(c) The Author(s) 2018. This article is an open access publication

\begin{abstract}
Purpose Despite the established role of O6-methyl-guanine-DNA methyltransferase (MGMT) as a marker for temozolomide response, consensus of the most reliable method to assess MGMT expression in pituitary adenomas is still missing. Currently, immunohistochemistry (IHC) assessment of formaldehyde fixed tissue samples is most widely used in a semiquantitative description. As formaldehyde fails to completely preserve nucleic acids, RCL2, an alcohol-based formaldehyde-free fixative, has been proposed as a more reliable alternative in terms of cell stability. Furthermore, as the current method of IHC is semiquantitative and observer-dependent, pyrosequencing, an objective tool to evaluate the methylation status of the MGMT promoter, has emerged as a reliable and accurate alternative. The aim of this study was to validate the current IHC method for assessment of MGMT protein expression in pituitary adenomas.

Methods The tissue samples of 8 macroadenomas with positive IHC MGMT expression ( $>50 \%)$ were investigated: first, we compared the time dependent stability of MGMT protein expression after pituitary adenoma removal between formaldehyde vs. RCL2. Then, we compared positive IHC MGMT expression with methylated promoter status using pyrosequencing.

Results In the first $12 \mathrm{~h}$ after adenoma removal, tissue samples remained MGMT positive in significantly more samples when fixated with formaldehyde than with RCL2, respectively (96 vs. 81\%, p=0.025).

Conclusion Our data confirm that the current method using formaldehyde tissue fixation and IHC reveals stable and reliable results of MGMT assessment in pituitary adenomas.
\end{abstract}

Keywords Pituitary adenoma $\cdot$ MGMT $\cdot$ Time dependent $\cdot$ Promoter methylation

\section{Introduction}

Aggressive pituitary adenomas and carcinomas pose a treatment challenge because they often remain incurable despite multiple surgeries, endocrine therapy and radiation treatment.

Temozolomide (TMZ), an alkylating agent, which is the mainstay of treatment for high-grade gliomas and advanced melanoma [1-4], has also shown effectiveness against aggressive pituitary adenomas and carcinomas [5-12].

Engelbert Knosp

engelbert.knosp@meduniwien.ac.at

1 Department of Neurosurgery, Medical University Vienna, Waehringer Guertel 18-20, 1097 Vienna, Austria

2 Institute of Neurology, Medical University of Vienna, Vienna, Austria
A positive response to TMZ has been found in association with downregulation of the DNA repair protein O6-methylguanine-DNA methyltransferase (MGMT) which removes alkylating adducts induced by TMZ and counteracts its antineoplastic action [6, 9, 11-22]. MGMT is a ubiquitously present protein in human cells but the amount of expression varies greatly within normal tissues. It is located on chromosome 10q26 and consists of 207 amino acids with a molecular mass of 21,645 Da [23-26] in human cells. The half-life of the mRNA as estimated in different cell lines is approximately $10 \mathrm{~h}[27,28]$.

Despite the established role of MGMT as a possible marker for TMZ response, consensus of the most reliable method to assess MGMT expression in pituitary adenomas is still missing. Currently, immunohistochemistry (IHC) assessment of formaldehyde fixed tissue samples is most widely used in a semiquantiative description [6, $9,11,12,15,21]$. Differences in methodology of MGMT 
immunostaining and assessment however, complicate the comparison of existing studies thus the clinical value of MGMT expression for pituitary tumours [12, 29, 30].

However, formaldehyde fails to completely preserve nucleic acids, and RCL2, an alcohol-based formaldehydefree fixative, has been proposed as a more reliable alternative in terms of cell stability [31-33]. Furthermore, the current method is semiquantitative and observer-dependent. Pyrosequencing, an objective tool to evaluate the methylation status of the MGMT promoter which detects pyrophosphate release on nucleotide of the next complementary nucleotide, has emerged as a reliable and accurate alternative in other tumor types [34].

The aim of this study was to validate the current IHC method for assessment of MGMT protein expression in pituitary adenomas.

\section{Materials and methods}

\section{Patient series}

We evaluated 8 MGMT positive pituitary adenomas of a consecutive series of 16 patients with macroadenomas (diameter $>1 \mathrm{~cm}$ ) at the immediate time point of tumor tissue removal. The tissue of these operations was divided into two equal parts, one for neuropathological examination the other for research purposes. The tumor samples were evaluated by the consent of the patients for further histopathological examination (EC Nr:1008/2014).

\section{Histopathologic examinations}

Immediately after surgical removal, each tumor sample was divided into 18 pieces of at least $2 \mathrm{~mm}^{3}$ size. In a time dependent mode (at $0 \mathrm{~min}, 30 \mathrm{~min}, 1 \mathrm{~h}, 2 \mathrm{~h}, 6 \mathrm{~h}, 12 \mathrm{~h}$ after operation) one piece was fixed in $4.5 \%$ neutral buffered formaldehyde and one in RCL2, respectively at each time. Furthermore, one piece was frozen in liquid nitrogen in case of possible unclear results or necessary evaluation at a later date.

All samples were embedded in paraffin, cut at $5 \mu \mathrm{m}$ and stained with both hematoxylin and eosin and the periodic acid-Schiff method. Paraffin-embedded tissue sections were examined immunohistochemically using the mouse monoclonal antibodies, MGMT (Ab-1, Clone MT 3.1; Waltham, Massachusetts, USA; 1:50 dilution). Staining was performed with a Ventana BenchMark ULTRA (Ventana Medical Systems Inc., Tucson, Arizona, USA) automated immunostainer.

After deparaffinization, $5 \mu \mathrm{m}$ thick sections have undergone heat-induced epitope retrieval in citrate buffer, $\mathrm{pH}$ 6.0. Tissue sections were incubated overnight at $4{ }^{\circ} \mathrm{C}$ with the primary antibody. The next day, sections were labelled with the appropriate secondary antibody, incubated with avidinbiotin-peroxidase, and visualized with a standard diaminobenzidine (DAB) detection kit (Ventana iVIEW DAB Universal Kit). Sections were then counterstained with Mayer's hematoxylin.

Positive control tissues for IHC consisted of paraffinembedded sections of colon cancer for immunostaining of MGMT. A positive internal control was done by staining of vascular endothelial cells. We used a non-relevant antibody of the same species (mouse) and of the same immunoglobulin isotype (IgG1) as negative control.

\section{Assessment}

For MGMT protein expression evaluation, each tumor sample was classified as: $<10,10-25,25-50,50-75$ and $>75 \%$ immunopositive cells $[9,35]$. According to their clinical relevance these groups were further stratified to the two distinguished groups, $<50 \%$ (negative and intermediate immunoexpression), $>50 \%$ (positive immunoexpression) as proposed $[35,36]$.

The immunoreactivity of MGMT was evaluated under light-microscopy at $\times 20-40$ magnification by three observers (A.M., A.W. and R.H) in a randomized and blinded mode. Only areas with highest immunoreactivity and minimal necrosis, fibrosis or other artifacts were selected for evaluation.

\section{Pyrosequencing}

For pyrosequencing analysis, $5 \mu \mathrm{m}$ slices were cut from the formaldehyde stained and paraffin embedded blocks and were investigated at the Institute of Cancer Research, Medical University of Vienna. DNA isolation was performed using the EpiTect FFPE Lysis Kit (Qiagen, Hilden, Germany) according to manufacturer's recommendations.

For definition of methylated/unmethylated MGMT promoter, the percentage mean value of the four investigated $\mathrm{CpG}$ dinucleotides (genomic sequence on chromosome 10 from 131,265,519 to 131,265,537:CGACGCCCGCAGGTC CTCG) was calculated.

A cut-off percentage of mean methylation, due to clinical relevance, was determined at $8 \%(<8 \%$ MGMT promoter unmethylated; $\geq 8 \%$ MGMT promoter methylated) as previous publications described for glioblastomas [34, 37, 38].

\section{Statistical analysis}

To assess differences within formaldehyde and RCL2 samples $\chi^{2}$ test was used. The same method was chosen to evaluate differences between IHC and pyrosequencing formaldehyde fixated samples. 
A p-value $<0.05$ was considered significant. For statistical analyses SPSS ${ }^{\circledR}$ version 23.0 software (SPSS Inc., Chicago, IL, USA) has been used.

\section{Results}

The tissue samples of 8 macroadenomas with positive IHC MGMT expression ( $>50 \%$ ) were investigated. The histological examination showed that there were 4/8 null-cell adenomas and 4/8 gonadotropinomas.

Table 1 Comparison of IHC MGMT expression > 50\%, formaldehyde vs. RCL2

\begin{tabular}{llll}
\hline Patient & $\begin{array}{l}\text { Formalde- } \\
\text { hyde }>50 \%\end{array}$ & RCL2 $>50 \%$ & $\mathrm{p}$ \\
\hline Patient 1 & $6 / 6$ & $6 / 6$ & $\mathrm{NS}$ \\
Patient 2 & $6 / 6$ & $0 / 6$ & 0.001 \\
Patient 3 & $6 / 6$ & $6 / 6$ & $\mathrm{NS}$ \\
Patient 4 & $5 / 6$ & $4 / 6$ & $\mathrm{NS}$ \\
Patient 5 & $6 / 6$ & $6 / 6$ & NS \\
Patient 6 & $5 / 6$ & $5 / 6$ & NS \\
Patient 7 & $6 / 6$ & $6 / 6$ & NS \\
Patient 8 & $6 / 6$ & $6 / 6$ & NS \\
Total & $46 / 48$ & $39 / 48$ & 0.025 \\
\hline
\end{tabular}

$N S$ non significant $(\mathrm{p}>0.05)$

Fig. 1 Boxplots of assessed time dependent MGMT expression in formaldehyde fixed tissue samples $x$-demonstrating the respective MGMT expression to the defined time point red line-demonstrating values above and below 50\% MGMT Expression
First, we compared the stability of MGMT protein expression after pituitary adenoma removal in formaldehyde vs. RCL2 in a time dependent mode. Then, we compared positive IHC MGMT expression with methylated promoter status using pyrosequencing.

\section{Formaldehyde vs. RCL2}

Overall eight pituitary adenoma samples fixated at six different time points, $46 / 48$ (96\%) formaldehyde cases remained positive (MGMT expression $>50 \%$ ), while 39/48 $(81 \%)$ cases showed stable results in the RCL2 group $(\mathrm{p}=0.025)$.

In one patient MGMT continued to be positive during the whole investigation period whereas in RCL2 samples every sample showed negative $(<50 \%)$ results $(\mathrm{p}=0.001)$. In one patient MGMT remained positive in 5/6 cases whereas all samples of RCL2 showed positive results $(p=0.296)$. In another patient, 5/6 formaldehyde samples were positive, however $2 / 5$ RCL2 samples were positive $(p=0.376)$ (Table 1) (Figs. 1, 2).

\section{Pyrosequencing}

We observed an unmethylated MGMT promoter in all adenoma tissue samples immediately after the operation (1.52-6.12\%). In 2/48 (4\%) cases the MGMT promoter changed to methylated (defining a cut-off for methylated MGMT promoter $\geq 8 \%$ ) in one patient after $1 \mathrm{~h}$ and

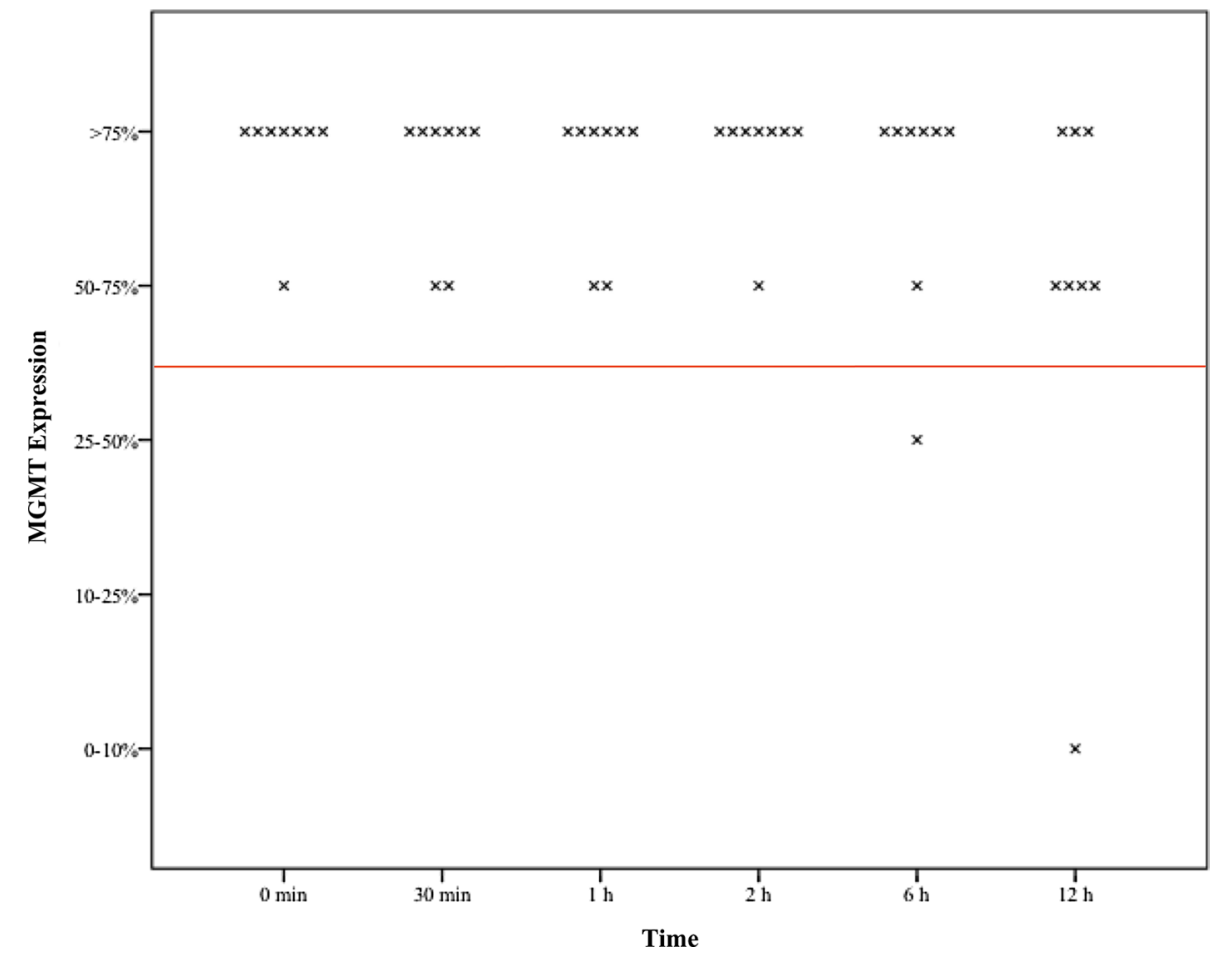




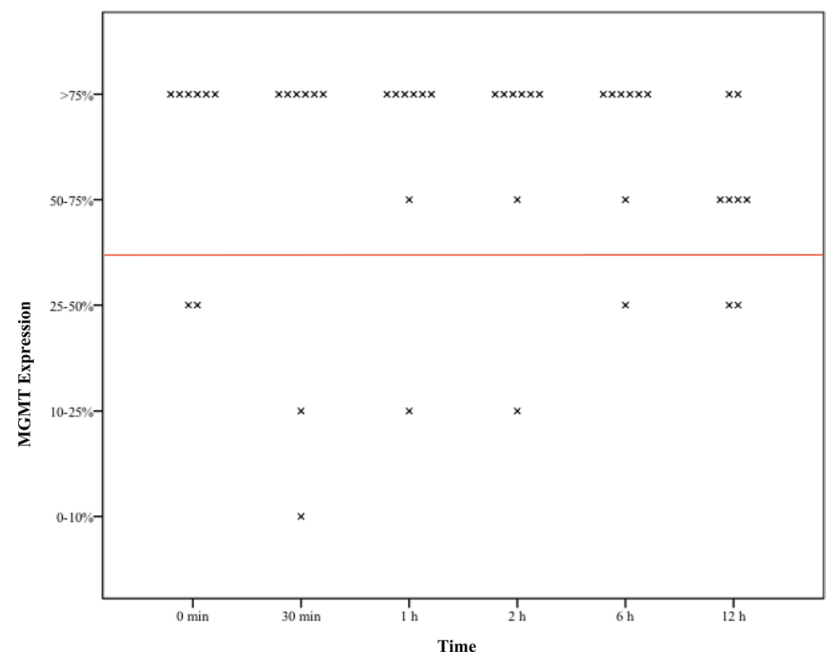

Fig. 2 Boxplots of assessed time dependent MGMT expression in RCL2 fixed tissue sample $\mathrm{x}$-demonstrating the respective MGMT expression to the defined time point red line-demonstrating values above and below 50\% MGMT expression

in another patient after $12 \mathrm{~h}$ after tumor removal. MGMT pyrosequencing results are shown in detail in Fig. 3.

\section{Discussion}

Aggressive pituitary adenomas and pituitary carcinomas unresponsive to multiple surgeries, drug treatment and radiotherapy pose a considerable therapeutic challenge. To date, chemotherapy with the alkylating drug TMZ has been the most effective treatment alternative for approximately half of these patients [5-13, 30, 36, 39-46].

In clinical routine, negative MGMT expression was found the most reliable predictive marker for tumor response to TMZ. However, MGMT expression was found to not correlate with biological tumor behavior and TMZ treatment success in every case (positive response to TMZ in only $73 \%$ of MGMT negative cases) [12]. In this respect, we validated the time-dependent stability of MGMT expression with the currently performed tissue fixation and assessment against alternative methods.

\section{Pyrosequencing}

Pyrosequencing, a relatively new technique compared to IHC, has proven stable interobserver results in promoter methylation analysis of glioblastoma samples and thus has found its way into clinical routine setting [34]. Furthermore, methylation of the $\mathrm{CpG}$ islands of the MGMT promoter has shown to correlate with loss of MGMT protein expression in tumor tissue [47]. This finding was also shown in pituitary adenomas using methylation analysis of the MGMT promoter. However, the frequency of methylation is considerably lower in pituitary tumors than in glioma cell lines [11]. Furthermore, pyrosequencing of promoter methylation in tumor samples can be contaminated with MGMT positive normal cells like leukocytes and endothelial cells and therefore maybe show false positive results [48-51].

A definitive cut-off for MGMT promotor methylation at the $\mathrm{CpG}$ position of $8 \%$ in pituitary adenomas, like in glioma cell lines, has not been defined to date. We applied the same
Fig. 3 Time dependent MGMT pyrosequencing results bold red line-demonstrating values above and below 8\% MGMT promotor methylation

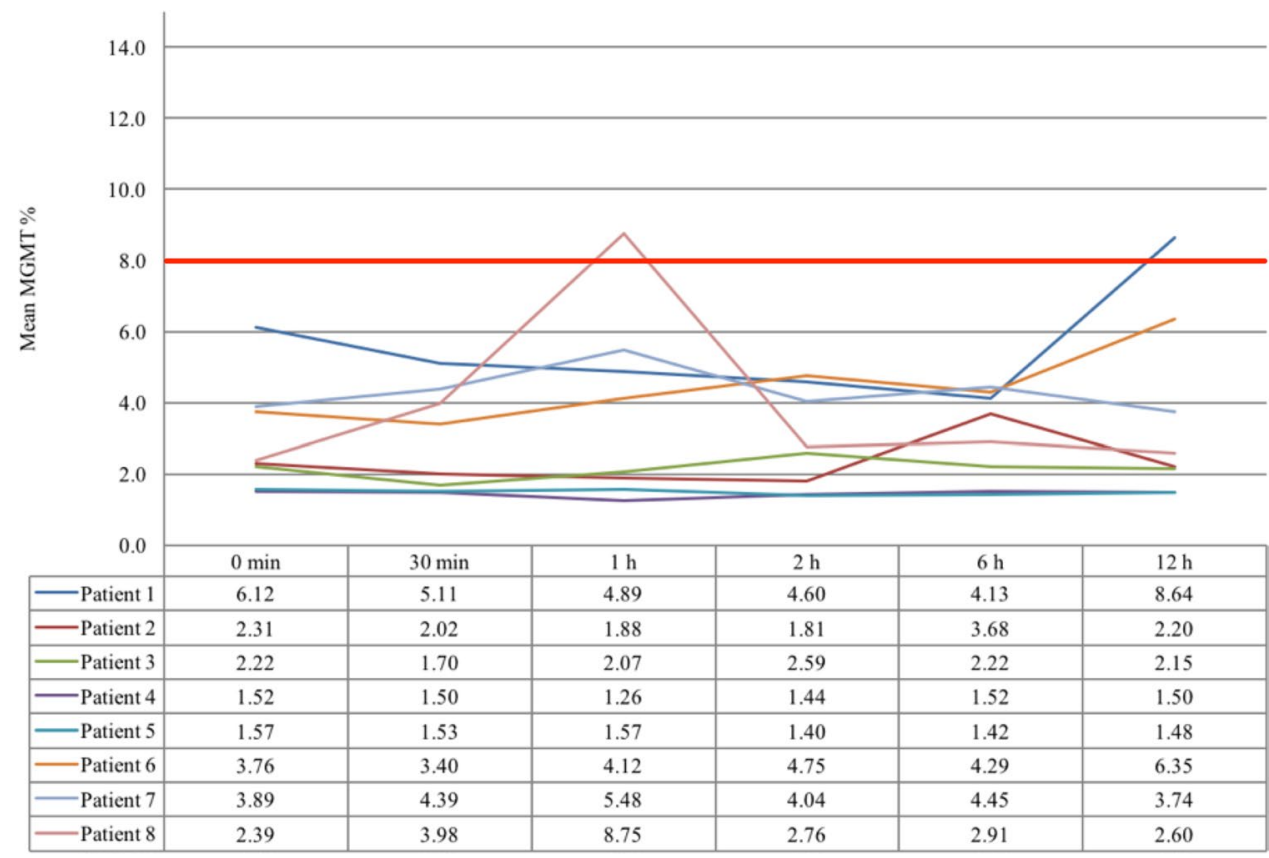



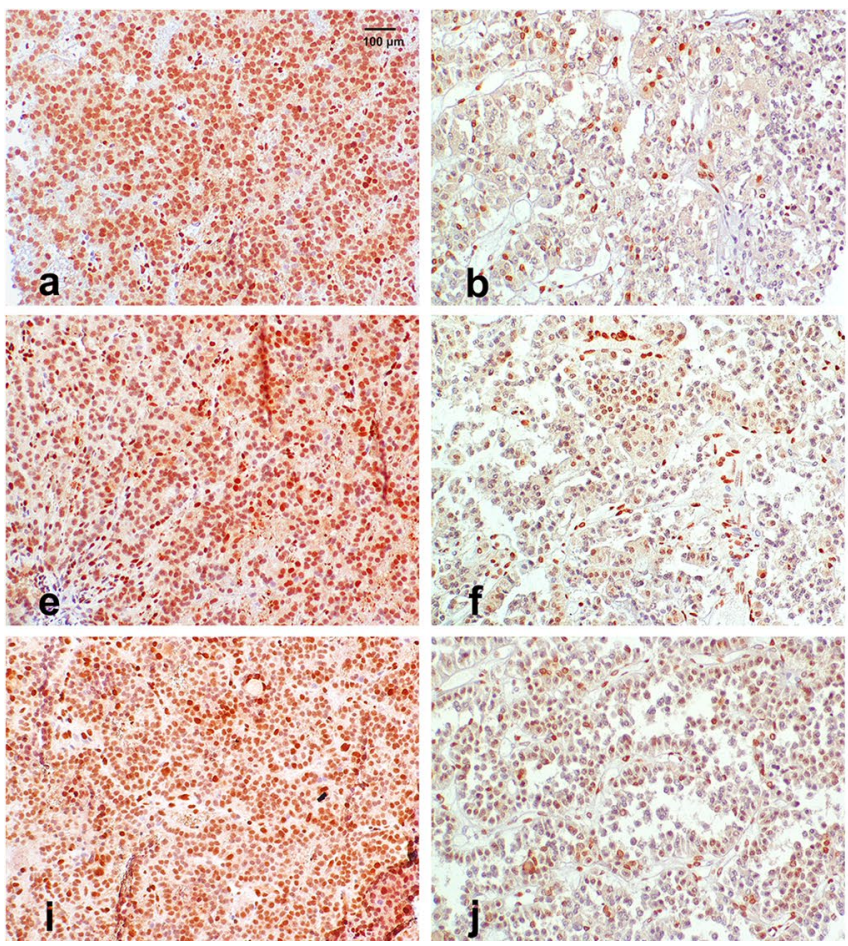

Fig. 4 Case 2: time dependent MGMT expression, $\times 40$ magnification (a, b) time point $=0$ min after tumour removal (a formalin $>75 \%$; b RCL2 $0-10 \%)$, c, $\mathbf{d}$ time point $=30$ min after tumour removal (c formalin 50-75\%; d RCL2 10-25\%), e, f time point $=1 \mathrm{~h}$ after tumour removal (e formalin 50-75\%; f RCL2 10-25\%), $\mathbf{g}$, h time point $=2 \mathrm{~h}$

criteria to the adenoma samples in our present series and revealed no statistical significant difference compared to MGMT positive IHC tissue samples.

However, comparing the costs between IHC and pyrosequencing at our institute, examinations revealed that taken into account only the pure costs for material (without acquisition or staff costs), the charges for one sample pyrosequencing were $63.5 €$ vs. $2.3 €$ for one IHC sample.

\section{Immunostaining of MGMT}

Differences in the technique of fixation, preservation and duration of paraffin-embedding have been reported to alter results in immunostaining of MGMT [11]. IHC has the advantage that technical expertise and equipment is widely available, in contrast to pyrosequencing. Furthermore, IHC allows differentiating between adenoma cells and non-neoplastic cells as well as identification of heterogeneity within tumor samples.

A relatively small variability of MGMT expression within a given pituitary adenoma has been attributed to the homogeneous population of adenoma cells in contrast to more heterogeneous glioma cells [52].
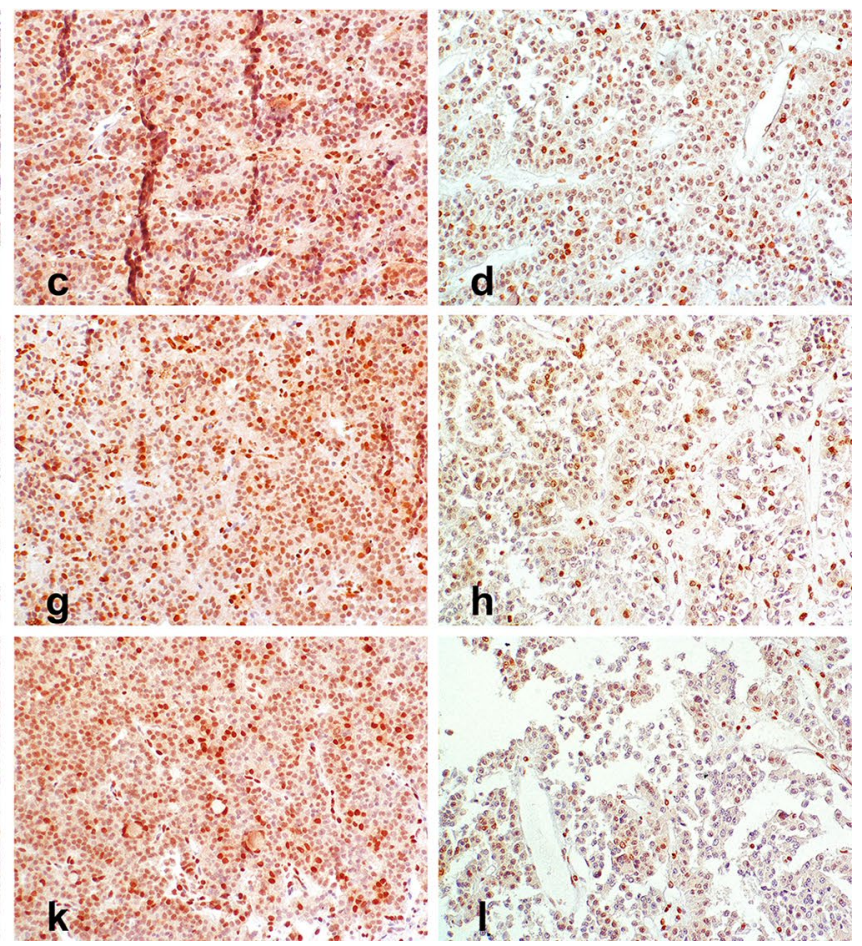

after tumour removal (g formalin $>75 \%$; h RCL2 10-25\%), i, j time point $=6 \mathrm{~h}$ after tumour removal (i formalin $>75 \%$; j RCL2 25-50\%), $\mathbf{k}, \mathbf{l}$ time point $=12 \mathrm{~h}$ after tumour removal (k formalin $50-75 \%$; l RCL2 25-50\%)

\section{Time of adenoma tissue fixation}

Furthermore, false negative results of MGMT expression may be due to different time points of fixation after tissue removal. The positive MGMT expression of neuron and glia cells has been found to decrease and vanish after exitus [53, 54]. We therefore investigated tissue samples over a time period of $12 \mathrm{~h}$ of 8 patients in detail to investigate a possible decrease of MGMT expression. We found that in formaldehyde fixation samples the results remained positive (IHC MGMT expression > 50\%) in $96 \%$ in formaldehyde fixed samples (Fig. 4).

\section{Conclusion}

In conclusion, our data confirm that the current method using formaldehyde tissue fixation and IHC reveals stable and reliable results of MGMT assessment in pituitary adenomas. 
Acknowledgements Open access funding provided by Medical University of Vienna. We thank Anita Brandstetter for evaluation of pyrosequencing results.

Funding This research did not receive any specific grant from any funding agency in the public, commercial or not-for-profit sector.

\section{Compliance with ethical standards}

Conflict of interest All authors have no financial interest/arrangement or affiliation with one or more organizations that could be perceived as a real or apparent conflict of interest in the context of the article.

Open Access This article is distributed under the terms of the Creative Commons Attribution 4.0 International License (http://creativecommons.org/licenses/by/4.0/), which permits unrestricted use, distribution, and reproduction in any medium, provided you give appropriate credit to the original author(s) and the source, provide a link to the Creative Commons license, and indicate if changes were made.

\section{References}

1. Middleton MR, Grob JJ, Aaronson N, Fierlbeck G, Tilgen W, Seiter S, Gore M, Aamdal S, Cebon J, Coates A, Dreno B, Henz M, Schadendorf D, Kapp A, Weiss J, Fraass U, Statkevich P, Muller M, Thatcher N (2000) Randomized phase III study of temozolomide versus dacarbazine in the treatment of patients with advanced metastatic malignant melanoma. J Clin Oncol 18(1):158-166

2. Stupp R, Mason WP, van den Bent MJ, Weller M, Fisher B, Taphoorn MJ, Belanger K, Brandes AA, Marosi C, Bogdahn U, Curschmann J, Janzer RC, Ludwin SK, Gorlia T, Allgeier A, Lacombe D, Cairncross JG, Eisenhauer E, Mirimanoff RO, European Organisation for R, Treatment of Cancer Brain., Radiotherapy T, G., National Cancer Institute of Canada Clinical Trials, G (2005) Radiotherapy plus concomitant and adjuvant temozolomide for glioblastoma. New Engl J Med 352(10):987-996. https:// doi.org/10.1056/NEJMoa043330

3. Augustine CK, Yoo JS, Potti A, Yoshimoto Y, Zipfel PA, Friedman HS, Nevins JR, Ali-Osman F, Tyler DS (2009) Genomic and molecular profiling predicts response to temozolomide in melanoma. Clin Cancer Res 15(2):502-510. https://doi. org/10.1158/1078-0432.CCR-08-1916

4. Neyns B, Tosoni A, Hwu WJ, Reardon DA (2010) Dose-dense temozolomide regimens: antitumor activity, toxicity, and immunomodulatory effects. Cancer 116(12):2868-2877. https://doi. org/10.1002/cncr.25035

5. Bengtsson D, Schroder HD, Andersen M, Maiter D, Berinder K, Feldt Rasmussen U, Rasmussen AK, Johannsson G, Hoybye C, van der Lely AJ, Petersson M, Ragnarsson O, Burman P (2015) Long-term outcome and MGMT as a predictive marker in 24 patients with atypical pituitary adenomas and pituitary carcinomas given treatment with temozolomide. J Clin Endocrinol Metab 100(4):1689-1698. https://doi.org/10.1210/jc.2014-4350

6. Bush ZM, Longtine JA, Cunningham T, Schiff D, Jane JA Jr, Vance ML, Thorner MO, Laws ER Jr, Lopes MB (2010) Temozolomide treatment for aggressive pituitary tumors: correlation of clinical outcome with $\mathrm{O}(6)$-methylguanine methyltransferase (MGMT) promoter methylation and expression. J Clin Endocrinol Metab 95(11):E280-E290. https://doi.org/10.1210/jc.2010-0441

7. Hagen C, Schroeder HD, Hansen S, Hagen C, Andersen M (2009) Temozolomide treatment of a pituitary carcinoma and two pituitary macroadenomas resistant to conventional therapy. Eur J Endocrinol 161(4):631-637. https://doi.org/10.1530/EJE-09-0389

8. Hirohata T, Asano K, Ogawa Y, Takano S, Amano K, Isozaki O, Iwai Y, Sakata K, Fukuhara N, Nishioka H, Yamada S, Fujio S, Arita K, Takano K, Tominaga A, Hizuka N, Ikeda H, Osamura RY, Tahara S, Ishii Y, Kawamata T, Shimatsu A, Teramoto A, Matsuno A (2013) DNA mismatch repair protein (MSH6) correlated with the responses of atypical pituitary adenomas and pituitary carcinomas to temozolomide: the national cooperative study by the Japan Society for Hypothalamic and Pituitary Tumors. J Clin Endocrinol Metab 98(3):1130-1136. https://doi.org/10.1210/ jc.2012-2924

9. Kovacs K, Scheithauer BW, Lombardero M, McLendon RE, Syro LV, Uribe H, Ortiz LD, Penagos LC (2008) MGMT immunoexpression predicts responsiveness of pituitary tumors to temozolomide therapy. Acta Neuropathol 115(2):261-262. https://doi. org/10.1007/s00401-007-0279-5

10. Losa M, Mazza E, Terreni MR, McCormack A, Gill AJ, Motta M, Cangi MG, Talarico A, Mortini P, Reni M (2010) Salvage therapy with temozolomide in patients with aggressive or metastatic pituitary adenomas: experience in six cases. Eur J Endocrinol 163(6):843-851. https://doi.org/10.1530/EJE-10-0629

11. McCormack AI, McDonald KL, Gill AJ, Clark SJ, Burt MG, Campbell KA, Braund WJ, Little NS, Cook RJ, Grossman AB, Robinson BG, Clifton-Bligh RJ (2009) Low $\mathrm{O}_{6}$-methylguanine-DNA methyltransferase (MGMT) expression and response to temozolomide in aggressive pituitary tumours. Clinical endocrinology 71(2):226-233. https://doi. org/10.1111/j.1365-2265.2008.03487.x

12. Raverot G, Sturm N, de Fraipont F, Muller M, Salenave S, Caron P, Chabre O, Chanson P, Cortet-Rudelli C, Assaker R, Dufour H, Gaillard S, Francois P, Jouanneau E, Passagia JG, Bernier M, Cornelius A, Figarella-Branger D, Trouillas J, Borson-Chazot F, Brue T (2010) Temozolomide treatment in aggressive pituitary tumors and pituitary carcinomas: a French multicenter experience. J Clin Endocrinol Metab 95(10):4592-4599. https://doi. org/10.1210/jc.2010-0644

13. Takeshita A, Inoshita N, Taguchi M, Okuda C, Fukuhara N, Oyama K, Ohashi K, Sano T, Takeuchi Y, Yamada S (2009) High incidence of low $\mathrm{O}(6)$-methylguanine DNA methyltransferase expression in invasive macroadenomas of Cushing's disease. Euro J Endocrinol/Euro Fed Endocr Soc 161(4):553-559. https://doi. org/10.1530/EJE-09-0414

14. Fealey ME, Scheithauer BW, Horvath E, Erickson D, Kovacs K, McLendon R, Lloyd RV (2010) MGMT immunoexpression in silent subtype 3 pituitary adenomas: possible therapeutic implications. Endocr Pathol 21(3):161-165. https://doi.org/10.1007/ s12022-010-9120-0

15. Lau Q, Scheithauer B, Kovacs K, Horvath E, Syro LV, Lloyd R (2010) MGMT immunoexpression in aggressive pituitary adenoma and carcinoma. Pituitary 13(4):367-379. https://doi. org/10.1007/s11102-010-0249-0

16. Syro LV, Ortiz LD, Scheithauer BW, Lloyd R, Lau Q, Gonzalez R, Uribe H, Cusimano M, Kovacs K, Horvath E (2011) Treatment of pituitary neoplasms with temozolomide: a review. Cancer 117(3):454-462. https://doi.org/10.1002/cncr.25413

17. Salehi F, Scheithauer BW, Kros JM, Lau Q, Fealey M, Erickson D, Kovacs K, Horvath E, Lloyd RV (2011) MGMT promoter methylation and immunoexpression in aggressive pituitary adenomas and carcinomas. J Neurooncol 104(3):647-657. https://doi. org/10.1007/s11060-011-0532-6

18. McCormack AI, Wass JA, Grossman AB (2011) Aggressive pituitary tumours: the role of temozolomide and the assessment of MGMT status. Eur J Clin Invest 41(10):1133-1148. https://doi. org/10.1111/j.1365-2362.2011.02520.x 
19. Moshkin O, Syro LV, Scheithauer BW, Ortiz LD, Fadul CE, Uribe H, Gonzalez R, Cusimano M, Horvath E, Rotondo F, Kovacs K (2011) Aggressive silent corticotroph adenoma progressing to pituitary carcinoma: the role of temozolomide therapy. Hormones 10(2):162-167

20. Zuhur SS, Tanik C, Karaman O, Velet S, Cil E, Ozturk FY, Ozkayalar H, Musluman AM, Altuntas Y (2011) MGMT immunoexpression in growth hormone-secreting pituitary adenomas and its correlation with Ki-67 labeling index and cytokeratin distribution pattern. Endocrine 40(2):222-227. https://doi.org/10.1007/ s12020-011-9485-y

21. Salehi F, Scheithauer BW, Kovacs K, Horvath E, Syro LV, Sharma S, Manoranjan B, Cusimano M (2012) O-6-methylguanine-DNA methyltransferase (MGMT) immunohistochemical expression in pituitary corticotroph adenomas. Neurosurgery 70(2):491-496. https://doi.org/10.1227/NEU.0b013e318230ac63

22. McCormack A, Kaplan W, Gill AJ, Little N, Cook R, Robinson B, Clifton-Bligh R (2013) MGMT expression and pituitary tumours: relationship to tumour biology. Pituitary 16(2):208-219. https:// doi.org/10.1007/s11102-012-0406-8

23. Hongeng S, Brent TP, Sanford RA, Li H, Kun LE, Heideman RL (1997) O6-Methylguanine-DNA methyltransferase protein levels in pediatric brain tumors. Clin Cancer Res 3(12 Pt 1):2459-2463

24. Nagane M, Kobayashi K, Ohnishi A, Shimizu S, Shiokawa Y (2007) Prognostic significance of O6-methylguanine-DNA methyltransferase protein expression in patients with recurrent glioblastoma treated with temozolomide. Japn J Clin Oncol 37(12):897-906. https://doi.org/10.1093/jjco/hym132

25. Kishida Y, Natsume A, Toda H, Toi Y, Motomura K, Koyama H, Matsuda K, Nakayama O, Sato M, Suzuki M, Kondo Y, Wakabayashi T (2012) Correlation between quantified promoter methylation and enzymatic activity of O6-methylguanine-DNA methyltransferase in glioblastomas. Tumour Biol 33(2):373-381. https://doi.org/10.1007/s13277-012-0319-1

26. Pieper RO (1997) Understanding and manipulating O6-methylguanine-DNA methyltransferase expression. Pharmacol Ther 74(3):285-297

27. Kroes RA, Erickson LC (1995) The role of mRNA stability and transcription in O6-methylguanine DNA methyltransferase (MGMT) expression in Mer + human tumor cells. Carcinogenesis 16(9):2255-2257

28. Fritz G, Tano K, Mitra S, Kaina B (1991) Inducibility of the DNA repair gene encoding O6-methylguanine-DNA methyltransferase in mammalian cells by DNA-damaging treatments. Mol Cell Biol 11(9):4660-4668

29. Raverot G, Castinetti F, Jouanneau E, Morange I, FigarellaBranger D, Dufour H, Trouillas J, Brue T (2012) Pituitary carcinomas and aggressive pituitary tumours: merits and pitfalls of temozolomide treatment. Clin Endocrinol (Oxf) 76(6):769-775. https://doi.org/10.1111/j.1365-2265.2012.04381.x

30. Annamalai AK, Dean AF, Kandasamy N, Kovacs K, Burton H, Halsall DJ, Shaw AS, Antoun NM, Cheow HK, Kirollos RW, Pickard JD, Simpson HL, Jefferies SJ, Burnet NG, Gurnell M (2012) Temozolomide responsiveness in aggressive corticotroph tumours: a case report and review of the literature. Pituitary 15(3):276-287. https://doi.org/10.1007/s11102-011-0363-7

31. Bellet V, Boissiere F, Bibeau F, Desmetz C, Berthe ML, Rochaix P, Maudelonde T, Mange A, Solassol J (2008) Proteomic analysis of RCL2 paraffin-embedded tissues. J Cell Mol Med 12(5B):20272036. https://doi.org/10.1111/j.1582-4934.2008.00186.x

32. Delfour C, Roger P, Bret C, Berthe ML, Rochaix P, Kalfa N, Raynaud P, Bibeau F, Maudelonde T, Boulle N (2006) RCL2, a new fixative, preserves morphology and nucleic acid integrity in paraffin-embedded breast carcinoma and microdissected breast tumor cells. J Mol Diagn 8(2):157-169. https://doi.org/10.2353/ jmoldx.2006.050105
33. Denouel A, Boissiere-Michot F, Rochaix P, Bibeau F, Boulle N (2011) An alternative fixative to formalin fixation for molecular applications: the RCL2((R))-CS100 approach. Methods Mol Biol 724:297-307. https://doi.org/10.1007/978-1-61779-055-3_19

34. Preusser M, Berghoff AS, Manzl C, Filipits M, Weinhausel A, Pulverer W, Dieckmann K, Widhalm G, Wohrer A, Knosp E, Marosi C, Hainfellner JA (2014) Clinical neuropathology practice news 1-2014: pyrosequencing meets clinical and analytical performance criteria for routine testing of MGMT promoter methylation status in glioblastoma. Clin Neuropathol 33(1):6-14

35. Widhalm G, Wolfsberger S, Preusser M, Woehrer A, Kotter MR, Czech T, Marosi C, Knosp E (2009) O(6)-methylguanine DNA methyltransferase immunoexpression in nonfunctioning pituitary adenomas: are progressive tumors potential candidates for temozolomide treatment? Cancer 115(5):1070-1080. https://doi. org/10.1002/cncr.24053

36. Micko ASG, Wohrer A, Hoftberger R, Vila G, Marosi C, Knosp E, Wolfsberger S (2017) MGMT and MSH6 immunoexpression for functioning pituitary macroadenomas. Pituitary. https://doi. org/10.1007/s11102-017-0829-3

37. Felsberg J, Thon N, Eigenbrod S, Hentschel B, Sabel MC, Westphal M, Schackert G, Kreth FW, Pietsch T, Loffler M, Weller M, Reifenberger G, Tonn JC, German Glioma N (2011) Promoter methylation and expression of MGMT and the DNA mismatch repair genes MLH1, MSH2, MSH6 and PMS2 in paired primary and recurrent glioblastomas. Int J Cancer 129(3):659-670. https:// doi.org/10.1002/ijc. 26083

38. Reifenberger G, Hentschel B, Felsberg J, Schackert G, Simon M, Schnell O, Westphal M, Wick W, Pietsch T, Loeffler M, Weller M, German Glioma G (2012) Predictive impact of MGMT promoter methylation in glioblastoma of the elderly. Int J Cancer 131(6):1342-1350. https://doi.org/10.1002/ijc.27385

39. Mohammed S, Kovacs K, Mason W, Smyth H, Cusimano MD (2009) Use of temozolomide in aggressive pituitary tumors: case report. Neurosurgery 64(4):E773-E774 (discussion E774). https://doi.org/10.1227/01.NEU.0000339115.12803.4E

40. Moyes VJ, Alusi G, Sabin HI, Evanson J, Berney DM, Kovacs K, Monson JP, Plowman PN, Drake WM (2009) Treatment of Nelson's syndrome with temozolomide. Eur J Endocrinol 160(1):115-119. https://doi.org/10.1530/EJE-08-0557

41. Curto L, Torre ML, Ferrau F, Pitini V, Altavilla G, Granata F, Longo M, Hofland LJ, Trimarchi F, Cannavo S (2010) Temozolomide-induced shrinkage of a pituitary carcinoma causing Cushing's disease-report of a case and literature review. Sci World J 10:2132-2138. https://doi.org/10.1100/tsw.2010.210

42. Ersen A, Syro LV, Penagos L, Uribe H, Scheithauer BW, Ortiz LD, Rotondo F, Horvath E, Kovacs K (2012) Non-uniform response to temozolomide therapy in a pituitary gonadotroph adenoma. Can J Neurol Sci 39(5):683-685

43. Ortiz LD, Syro LV, Scheithauer BW, Ersen A, Uribe H, Fadul CE, Rotondo F, Horvath E, Kovacs K (2012) Anti-VEGF therapy in pituitary carcinoma. Pituitary 15(3):445-449. https://doi. org/10.1007/s11102-011-0346-8

44. Whitelaw BC, Dworakowska D, Thomas NW, Barazi S, Riordan-Eva P, King AP, Hampton T, Landau DB, Lipscomb D, Buchanan CR, Gilbert JA, Aylwin SJ (2012) Temozolomide in the management of dopamine agonist-resistant prolactinomas. Clin Endocrinol 76(6):877-886. https://doi. org/10.1111/j.1365-2265.2012.04373.x

45. Batisse M, Raverot G, Maqdasy S, Durando X, Sturm N, Montoriol PF, Kemeny JL, Chazal J, Trouillas J, Tauveron I (2013) Aggressive silent GH pituitary tumor resistant to multiple treatments, including temozolomide. Cancer Investig 31(3):190-196. https://doi.org/10.3109/07357907.2013.775293

46. Murakami M, Mizutani A, Asano S, Katakami H, Ozawa Y, Yamazaki K, Ishida Y, Takano K, Okinaga H, Matsuno A (2011) 
A mechanism of acquiring temozolomide resistance during transformation of atypical prolactinoma into prolactin-producing pituitary carcinoma: case report. Neurosurgery 68(6):E1761-E1767. https://doi.org/10.1227/NEU.0b013e318217161a (discussion E1767)

47. Esteller M, Hamilton SR, Burger PC, Baylin SB, Herman JG (1999) Inactivation of the DNA repair gene O6-methylguanine-DNA methyltransferase by promoter hypermethylation is a common event in primary human neoplasia. Cancer Res 59(4):793-797

48. Sasai K, Nodagashira M, Nishihara H, Aoyanagi E, Wang L, Katoh M, Murata J, Ozaki Y, Ito T, Fujimoto S, Kaneko S, Nagashima K, Tanaka S (2008) Careful exclusion of non-neoplastic brain components is required for an appropriate evaluation of O6-methylguanine-DNA methyltransferase status in glioma: relationship between immunohistochemistry and methylation analysis. Am J Surg Pathol 32(8):1220-1227. https://doi.org/10.1097/ PAS.0b013e 318164c3f0

49. Silber JR, Blank A, Bobola MS, Mueller BA, Kolstoe DD, Ojemann GA, Berger MS (1996) Lack of the DNA repair protein O6-methylguanine-DNA methyltransferase in histologically normal brain adjacent to primary human brain tumors. Proc Natl Acad Sci USA 93(14):6941-6946

50. Cao VT, Jung TY, Jung S, Jin SG, Moon KS, Kim IY, Kang SS, Park CS, Lee KH, Chae HJ (2009) The correlation and prognostic significance of MGMT promoter methylation and MGMT protein in glioblastomas. Neurosurgery 65(5):866-875. https://doi. org/10.1227/01.NEU.0000357325.90347.A1 (discussion 875).

51. Preusser M, Charles Janzer R, Felsberg J, Reifenberger G, Hamou MF, Diserens AC, Stupp R, Gorlia T, Marosi C, Heinzl H, Hainfellner JA, Hegi M (2008) Anti-O6-methylguanine-methyltransferase (MGMT) immunohistochemistry in glioblastoma multiforme: observer variability and lack of association with patient survival impede its use as clinical biomarker. Brain Pathol 18(4):520-532. https://doi.org/10.1111/j.1750-3639.2008.00153.x

52. Rodriguez FJ, Thibodeau SN, Jenkins RB, Schowalter KV, Caron BL, O’Neill BP, James CD, Passe S, Slezak J, Giannini C (2008) MGMT immunohistochemical expression and promoter methylation in human glioblastoma. Appl Immunohistochem Mol Morphol 16(1):59-65. https://doi.org/10.1097/PAI.0b013e31802fac2f

53. Nakasu S, Fukami T, Baba K, Matsuda M (2004) Immunohistochemical study for O6-methylguanine-DNA methyltransferase in the non-neoplastic and neoplastic components of gliomas. J Neurooncol 70(3):333-340

54. Hsu CY, Ho HL, Chang-Chien YC, Chang YW, Ho DM (2015) MGMT promoter methylation in non-neoplastic brain. J Neurooncol 121(3):459-467. https://doi.org/10.1007/s11060-014-1663-3 